\section{Council Meeting in Grenoble 26/27 March}

A full report of the meeting of the Council which was held in Grenoble, 26/27 March will be published in the May issue of Europhysics News. Here we shall content ourselves with noting the results of elections and changes of office and one change in the Society's rules.

This last concerned a change to Rule 34 which governs the procedure for changing the unit fee - the basic element in the subscription structure. The amounts to be paid by the Individual Ordinary Members ( $4 A$ and $4 C$ ) and the national societies (4B) are expressed in terms of the unit fee so that a change is spread proportionately over all the contributors.

In the days when it was expected that there would be several Council meetings in any year it was stipulated that at least six months notice had to be given of any change. With inflation at the level common in Europe, and Switzerland following the fashion, such a procedure is now considered unwieldy and it was proposed that the notification period be reduced to three months.

Some ambiguity exists in the wording of Rule 41 concerning the way in which Rule 34 may be modified but Council agreed unanimously that it was in order for a decision to be taken at the meeting. Then only one delegation represented (the USSR Academy of Sciences) abstained when the motion was put, all others were in favour, so that the relevant sentence in Rule 34 now reads:

"Any proposal by the Executive Committee to increase the unit fee shall be submitted in writing to all Ordinary Members and Fellows at least three months before the Council is to meet to decide the matter."

The exact proposal for an increase has yet to be finalized but one will be prepared for publication in Europhysics News in May, so that a decision can be taken by Council at its meeting in Istanbul on the morning of Sunday, 6 Sept.

\section{Executive Committee}

Council elected as the Executive Committee of the European Physical Society for the next 12 months the following:

President: A.R. Mackintosh, Copenhagen Vice-President: J. Friedel, Orsay

Secretary: L.A.A. Thomas, Wembley

Vice-Secretary: H. de Waard, Groningen

Treasurer: E.A. Mueller, Geneva

Vice-Treasurer: D. Kuhn, Innsbruck

Members: K.E. Ganzhorn, Stuttgart

A. Milojevic, Belgrade

G. Preparata, Bari

K.K. Rebane, Tallinn

\section{Delegates of I.O.M.s}

Following the postal ballot of all the Individual Ordinary Members, the members listed below have been elected as representatives of Category $4 \mathrm{~A}$ and $4 \mathrm{C}$ on the Council for three years:
K. Bethge, Frankfurt/Main
J. Devreese, Antwerp
F. Fumi, Genoa
J. Niederle, Prague

with as first alternate:

R.M. Bonnet, Verrières-le-Buisson

These delegates now take the places vacated by:

G. Eilenberger, Jülich

C. Hilsum, Great Malvern

A. Janner, Nijmegen

J.P. Toennies, Göttingen

all of whom had completed their full term in office.

\section{Advisory Committee on Publications}

The Executive Committee approved the appointment of G. Eilenberger as Chairman of the Advisory Committee on Publications. He will now take over from E.R. Dobbs who has been forced to resign because of the pressure of his many duties at Bedford College.
J. Kaczer, Prague

\section{Divisional Elections}

As a result of the elections in three of the Sections of the Condensed Matter Division their Committees are as follows:

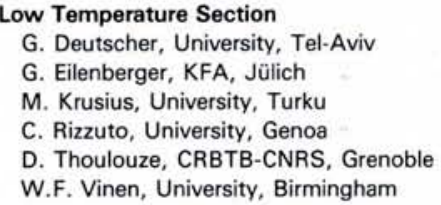

G. Deutscher, University, Tel-Aviv

G. Eilenberger, KFA, Jülich

M. Krusius, University, Turku

C. Rizzuto, University, Genoa

D. Thoulouze, CRBTB-CNRS, Grenoble

W.F. Vinen, University, Birmingham

Metals Section

D. Buschow, Philips Research Labs, Eindhoven

G. Caglioti, Institute of Nuclear Engineering, Milan

R.M.J. Cotterill, Technical University, Lyngby

D.J. Fabian, Strathclyde University, Glasgow

O. Fischer, University, Geneva

J.P. Gaspard, University, Liège

Surfaces and Interfaces Section

G. Benedek, Institute of Physics, Milan

G. Ertl, University, Munich

B. Feuerbacher, ESA, Noordwijk

B.I. Lundqvist, Chalmers University, Göteborg A. van Oostrom, Philips Research Labs., Eindhoven R.F. Willis, University, Cambridge

\section{National Societies}

New President of the Finnish Physical Society is T. Katila of the Helsinki University of Technology, Espoo.

Both the Finnish Physical Society and the Romanian National Committee for Physics have arranged that the membership fees of I.O.M.'s in their country can be paid now through the national society.

New President of the French Physical Society is A. Blanc-Lapierre, of the Ecole Supérieure d'Electricité, Gif-sur-Yvette.

The Institute of Physics announces that in future, EPS members will benefit from the same advantageous rates for attending its conferences as I.O.P. members.

Copies of Careers with Physics, a booklet in colour of 20 pages published by the Institute of Physics setting out the jobs that are open to people who have studied physics - up to the age of 18 , or beyond - can be obtained, free of charge, from M.G. Ebison, Education Officer at the Institute of Physics, 47 Belgrave Square, London SW1X 80X.

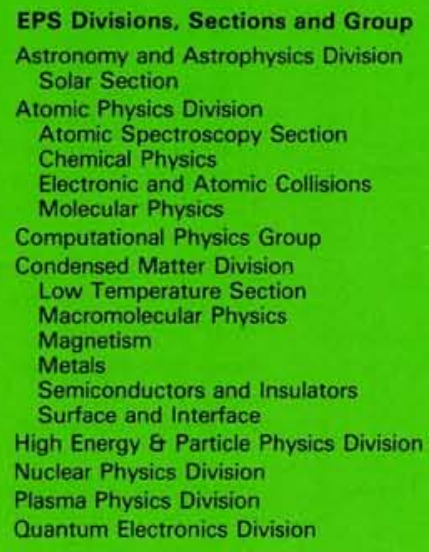

Europhysics News is the official journal of the European Physical Society that comprises 28 National Societies. Academies and Groups, over 3000 Individual Ordinary Members and 30 Associate Members. Governing bodies of EPS are the General Meeting, Council and an elected Executive Committee responsible for detailed policy. Executive Committee responsible for detailed policy.
EPS promotes the collaboration of physicists through out Europe and encourages all aspects of international exchange in physics. EPS awards scholarships for research and studies and makes arrangements for teaching abroad. EPS publishes, in addition to Europhysics Newing abroad. EPS publishes, in addition to Europhysics News, Europhysics Conference Abstracts, the Procee
dings of its General Conferences and (with the I.O.P. the European Journal of Physics. Individual Ordinary Members receive Europhysics News (subscription for non-members: $75 \mathrm{Sw}$.Fr./a), substantial rebates on non-members: $75 \mathrm{SW}$.Fr./a), substantial rebates on Application for membership is made through the permanent Secretariat in Geneva. Annual subscription for members of a National Society is $32 \mathrm{Sw}$. Fr.

\section{Editor: E.N. Shaw \\ Meetings Compilation: W.S. Newman \\ Editorial Board: \\ K. Appert, A. Baratoff, G.J. Béné, \\ G.R. Macleod, A. Maeder, J. Muller \\ Editorial and Advertising Office at the EPS Secretariat. \\ Address: EUROPEAN PHYSICAL SOCIETY P. O. Box 69 , CH-1213 Petit-Lancy 2 Switzeriand \\ Telephone: Geneva (22) 931130 \\ Telex: 23455 alarm ch \\ Cables: europhys genève \\ Printed by: Pfirter frères SA $\mathrm{CH}-1213$ Petit-Lancy/Switzerland}

